\title{
The Emergence of Civil Disobedience: A Comparison during Dr. Mahathir and Abdullah Badawi's Era
}

Zawiyah Mohd Zain

Senior Lecturer, School of Government, College of Law, Government and International Studies,

Universiti Utara Malaysia 06010 Sintok, Kedah.

Email: zawie98@yahoo.com

\section{Mohammad AgusYusoff}

Associate Professor, School of History, Politics and Strategy, Faculty of Social Sciences and Humanities, Universiti Kebangsaan Malaysia , 43600 Bangi, Selangor Email: agus_ukm@yahoo.com

\section{Doi:10.5901/mjss.2015.v6n1s1p279}

\section{Abstract}

Civil disobedience is not new in Malaysia. It has been going on since the days of Tunku Abdul Rahman. However, it did not explode until the final phase of the reign of Dr. Mahathir in 1998. While in 2007 there was widespread civil disobedience when people were not satisfied with the administration of Abdullah Badawi. The purpose of this article is to analyze the factors that caused at the time of the occurrence of civil disobedience during the era of Dr. Mahathir and Abdullah Badawi. Results show that the main reason for the occurrence of civil disobedience at the time of Dr. Mahathir was due to the grievances of the people on the issue of the dismissal of Anwar Ibrahim. Whereas at the time of Abdullah Badawi the emergence of civil disobedience is caused by the weakness of his leadership. In addition, the analysis also found that civil disobedience affect the outcome of the general elections in 1999 and 2008 when the Barisan Nasional (National Front) performance deteriorated badly in the General Elections. The Barisan Nasional decline in the general election of 2008 resulted in Abdullah Badawi's resignation in April 2009

Keywords: civil disobedience, general election, Barisan Nasional, Dr. Mahathir, Abdullah Badawi.

\section{Introduction}

Since gaining independence in 1957, Malaysia has been ruled by six Prime Ministers (PM). Of all the PMs, Dr. Mahathir Mohamad was the longest serving Prime Minister. During his reign of 22 years, there were series of civil disobedience due to dissatisfaction of the people related to civil and political rights. The most intense civil disobedience was in 1998 following the dismissal of the then Deputy Prime Minister (DPM), Anwar Ibrahim. However, this civil disobedience could not bring down the government under Dr. Mahathir, and later he was resigned in September 2003. After Abdullah Badawi took over the leadership of the country in 2003 , he had a unique way to regain public support for the Barisan Nasional (BN), which performance dropped in the 1999 general election.As a result he was able to bring victory for the BN in the 2004 general election. However, in 2007 a civil disobedience reappeared and caused BN performance to deteriorate badly in the 2008 general elections.

This article aims to compare the scenarios of civil disobedience in the era of Dr. Mahathir and Abdullah Badawi. The objective of this article is to discuss: first, the reason of the emergence of civil disobedience during both era, Dr. Mahathir and Abdullah Badawi. Second, is to analyze the impact of civil disobedience on election result which is Malaysia's $10^{\text {th }}$ general election in 1999 and Malaysia's $12^{\text {th }}$ general election in 2008. This study is significance to the political parties, to note that election result will be influence by several factors includes internal and external factors. Among the questions discussed are: What are the factors responsible for the emergence of civil disobedience at the time of Dr. Mahathir and Abdullah Badawi? Is there any difference in the cause of civil disobedience during both periods? And to what extent is the strength of the civil disobedience? To answer the questions which are raised, this article will be divided into several parts: the first discusses the concept of civil disobedience. The second part discusses the background of Dr. Mahathir and Abdullah Badawi's administration. The third, analyzes the reasons of the emergence of civil disobedience and its impact on the election result. 


\section{The Concept of Civil Disobedience}

According to Rawsl (1971:363) civil disobedience are peaceful public action,done openly, is a political act contrary to law and are usually intended for demanding changes to the law or government policy.Rawls in his argument also noted that civil disobedience usually occurs in civil society as the space for their voices have been closed altogether. Therefore, the changes they demand is for the government to implement a democratic and free society in order to speak out.

Ralws definitions were adopted by Bedau (1991:51), he said civil disobedience are "... acts which are illegal, committed openly, non-violently, and conscientiously, within the framework of the rule of law and with the intention of frustrating or protesting some law, policy, or decision of the government (or some of its officers)." In this definition Bedau emphasizes that civil disobedience are done peacefully as a result of frustration with the government or government officials. Bedau cited examples of public frustration over the government's actions are due to injustice in society through unfair legislation such as discrimination against African-American community in the United States.

Rawls and Bedau definition was later reinforced by Smith (2004). For Smith (2004:353) civil disobedience is "...public, illegal and political protest carried out against state or policies... acts of civil disobedience might be justified within a constitutional democracy. Justification here is understood as a moral or political justification-where civilly disobedient citizens claim that they are morally or politically entitle to disobey law." This definition states that civil disobedience is a public action and also political action committed against the government or its policies. Smith argued civil disobedience was based on three main principles: when a group of people are excluded from the process of public participation (such as prevented from voting), when the authorities manipulate the situation for their benefit (such as media control) and when the government did not seek the views of the community in formulating public policy.

In conclusion, all the above scholars agree that civil disobedience is a public action against the law and government policies that conflict with the aspirations of the people. It is done either on the ground of morality, religion, justice, or others.

\section{Research Methodology}

The whole analysis in this article is qualitative and derived from two types of data. The primary data is generated through in-depth interviews with individuals who are experience and knowledgeable about the subjects under study. They are representative of the government political party, opposition party and non-governmental organizations (NGOs). Government political party includes Barisan Nasional (National Front), Malaysian Chinese Association and Malayan Indian Congress. Oppositon party includes People's Justice Party (PKR), Malaysia Islamic Party (PAS) and Democratic Action Party (DAP). The secondary data is obtained from books, journals, previous studies and documents from government departments. This study using a qualitative methode because interviews techniques are the most appropriate way to get the detail information that informant were experience. According to Bogdan \& Biklen (2007) \& Merriam (2009), the advantages of this type of analysis are that it can generate understanding, discovery and contribute to the overall activity or phenomenon. This is because it provides detailed analysis on a small number of individuals or cases through direct conversation, and detail explanation of the program, situation, individual, interaction and behaviour observation. In addition, qualitative analysis also provides a significant contribution to basic knowledge in particular field.

\section{Findings and Discussion}

\subsection{Malaysian Politics in the Era of Dr. Mahathir}

Dr. Mahathir Mohammad was appointed as the PM of Malaysia in July 1981. At the beginning of his reign he was so committed to making a difference through new policies and programs are more positive in the administration and politics. Among them is a more liberal attitude towards political prisoners by releasing 21 political detainees under the Internal Security Act (ISA) in August 1981. In addition, the administrative atmosphere also changed a lot in which he stressed the quality of public services and a determination to eradicate corruption, improve bureaucratic efficiency and curb political disputes at the federal and state levels. However, by the next phase there emerged various issues which raised objections from the community. For example, around the year 1984 to 1989, there was civil disobedience related to development and environment (Brown 2004:135). It involves protest by the Chinese community in Bukit Papan, Perak. This is because the government's decision to allow the development of a radioactive waste site near Chinese residential areas by the Asian Rare Earth (ARE). Several protests were held in 1984 to 1987 that attracted thousands of people to participate, including Democratic Action Party (DAP) and Perak Anti Radioactive Committee (PARC). 
Furthermore, in 1986 a public outcry occurred in connection with the government amendment to the Official Secrets Act (OSA). The government was amended the act when the issue of Bumiputera Malaysia Finance (BMF) corruption was made public through the Far Estern Economic Review and the Asian Wall Street Journal (AWSJ). AWSJ in exposing BMF, had connected the then finance minister, Daim Zainuddin, to the issue. The government also was banned AWSJ and cancel the permit of the journalists of that newspaper.

This issue has finally been brought to the Supreme Court and the ban was lifted forcing the government to propose amendments to the OSA (Means 1991:197; Brown 2004:126). The amendments were to enable government documents treated as confidential and shall not be disclosed to the public, unless otherwise stated. The government's actions to amend OSA caused a demonstration by about 2000 journalists. The National Association of Journalists also collected 36,000 signatures of the from the public as a sign of protest to the amendments. Meanwhile, organizations like the Muslim Youth Movement of Malaysia (ABIM), Aliran Kesedaran Negara (Aliran or National Consciousness Movement), Consumers Association of Penang (CAP) and the Bar Council also held a protest by organizing dialogues named as the Movement for Freedom and Justice (Brown 2004:127 ). However, the protest did not produce any result as the Parliament passed the amendments in December 1986 by 131 votes as against 21 who opposed (Brown 2004:127). Despite the protests, the government under the leadership of Mahathir was succesful in dealing with various problems and crises that arose in every phase of his reign.

\subsection{Abdullah Badawi Administration}

Abdullah Badawi was appointed as Prime Minister of Malaysia in September 2003 after Dr. Mahathir's resignation. After holding the position of PM he promised to make changes in the administration and politics. As a result he was able to bring victory for the Barisan Nasional in the 2004 General Elections. In this general election BN got 90.4 percent of the parliamentary seats which is BN's best performance. However, after four years of his reign, Abdullah Badawi failed to implement the changes, causing the people to be dissatisfied. This is because first, Abdullah Badawi did not fulfill his promise to make changes as talked about from the beginning of his reign, especially in connection with the restoration of democracy, eradicating corruption and improving public services. Second, the administration of Abdullah Badawi was overshadowed by the intervention of his family, especially Khairy Jamaluddin. This issue became serious when the former Prime Minister Dr. Mahathir revealed through his blog. Third, the current economic uncertainty causing the government to raise fuel prices. As a result of the increase it has an impact on rising prices of goods, thus contributing to the higher cost of living.

Finally, the failure of Abdullah Badawi in addressing religious issues between Muslims and non-Muslims. In the second phase of his rule there was tension between Muslims and non-Muslims in relation to some matters that involve a number of decisions of the Syariah courts. Among the public attention is the case of Lina Joy. Cases involving Lina Joy is related to a failure to apply for a change of name and status from Islam to Christianity on the grounds that she was no longer a Muslim. Moreover, the action of Local Authorities in demolishing Hindu temples in Selangor State also angered the community, especially the Indians. Among the temples were Sri Mariamman temple and several other temples which were demolished in Shah Alam on October 30 and November 15, 2006.

\subsection{Civil disobedience in Dr. Mahathir and Abdullah Badawi's Era}

During the time of Dr. Mahathir civil disobedience has occurred since the beginning of his reign. However it became larger when the advent of the reform movement in 1998. The question is what are the causes of massive civil disobedience in 1998? Civil disobedience cases in 1998 had to do with the policy or government actions. The final phase of the reign of Dr. Mahathir (1998-2003) is the most challenging phase. Dr. Mahathir himself in his latest book A Doctor in the House: The Memoirs of Tun Dr. Mahathir Mohamad agreed to this. He said 1998 was the most challenging year for him as a PM because of the economic crisis, the event of Commonwealth Games and also Anwar Ibrahim's sacking as DPM and the then Finance Minister (Mahathir 2011:699).

The removal of Anwar Ibrahim in 1998 was a turning point in national politics. This is because even Anwar Ibrahim was sacked on the grounds of corruption and sexual misconduct, he claim as a political conspiracy orchestrated by Dr. Mahathir because of differences between them in dealing with the economic problems. For example, Anwar Ibrahim is more likely to see the cause of the economic downturn as due to problems including those related to corruption, cronyism and nepotism. He also felt that the government should follow the recovery plan by the International Monetary Fund (IMF), that is, the defense of the dollar by keeping interest rates high. While Dr. Mahathir often shifted the blame on outside parties and plans to solve the problem internally without outside interference. In addition he was provided assistance for 
distressed local companies. Anwar did not agree to the approach because he considered the aid was to save the cronies of Dr. Mahathir (Hilley 2001:105).

Therefore, Anwar Ibrahim did not easily give in and after he was fired he crisscrossed country for 18 days to explain what really happened. In each presentation, he explained the political conspiracy to topple him. Anwar Ibrahim also revealed some of the Mahathir administration practices related to corruption, cronyism, nepotism and waste of public money through mega projects and the use of state funds to rescue some cronies of Mahathir (Weiss, 2006). In a series of talks he was launched a reform movement to urge his followers to fight for justice, better governance, accountability, policies to benefit the economically weak, freedom and democracy (Weiss 1999:26). The reform movement was officially launched on 12 September 1998 in Permatang Pauh, Penang.

Next, the call for reform was greeted with enthusiasm, not only by supporters but also by other communities such as NGOs, opposition parties, student groups, private and public sector workers until finally they came out to demonstrate civil disobedience through demonstrations. For instance, on September 20, before he was arrested, the first mass demonstration led by Anwar Ibrahim was held at the National Mosque and Merdeka Square. This demonstration attracted the support from the community, especially young people, estimated up to 40,000 people, leading to the arrest of Anwar Ibrahim on the night. It was the largest demonstration in the history of Malaysian politics, and gained widespread reports from international media, which were covering the Commonwealth Games in Malaysia at that time (Abbot 2000:246; Shela Nair 2007:351; Lee, J.C.H 2010:48). After the reform, Dr. Mahathir stepped down in 2003.

Whereas at the time of Abdullah Badawi especially in second phase of his administration arose a variety of things that revealed the weaknesses in his administration. Therefore people was unhappy and eventually rallied to show the protest. This is consistent with Bedau (1991) who states that civil disobedience are done ".... with the intention of showing frustration by protesting against some laws or policies or decisions of the government (or some of its Officers)."

The civil disobedience began by writing on the Internet. For example, in 2007 there were various blogs whether political or others that criticized the leadership of Abdullah Badawi. The authors of these blogs were not only among the common people but they were individuals who had been with the government a long time ago. For example, there were blogs by Dr. Mahathir, former Prime Minister of Malaysia, Kadir Jassin, a former chief of the New Straits Times Press (NSTP) and Ahmad Ruhainie a former Member of Parliament.

The government take no actions about the criticism on the Internet and resulted in people returning to the streets to demonstrate. The largest demonstration was by BERSIH group and Hindu Rights Action Force (HINDRAF). BERSIH is a combination of a number of NGOs demanding fair and clean elections. BERSIH rally was held on 10 November 2007. The rally received approximately 30,000 people involving different races demanding a change in the electoral process to be more transparent and fair. Their purpose was to march to Istana Negara to hand over a memorandum to the Yang diPertuan Agong (King) on allegations that the Election Commission (EC) was unfair and favor the BN.

BERSIH claims include reviewing of the existing electoral rolls, using the permanent ink in the process of voting, the abolition of postal voting and fair media coverage for all political parties. As a result of the rally police charged 17 people for a rally without a permit (Ooi Kee Beng, 2008b: 11; Johan Saravanamuttu 2008:49; Gatsiounis 2008:59-60). Whereas, the Hindraf demonstration was held on 25 November 2007. Hindraf purpose was to protest a number of issues including the demolition of Hindu temples by local authorities. Even before the demonstrations, the government has banned the HINDRAF rally, which was held and involved the participation of more than 30000 people. This led the authorities to take action to disperse the protestors by using tear gas and water cannons. In addition, the police also held roadblocks at major roads which caused so much traffic jams. As a result of the demonstrations, the government arrested 240 people who were involved in the demonstrations, while some of the main leaders of Hindraf including Waythamoorty, Uthayakumar and VS Ganapathi were detained under the Internal Security Act (ISA) (Maznah Mohamad 2008:444; Johan Saravanamuttu 2008: 46-47; Ooi Kee Beng 2009:10-11).

Results show that massive civil disobedience by reform movements was caused by the combination of sacking of Anwar Ibrahim as well as government misconduct in the case of corruption, abuse of power and nepotism exposed by Anwar Ibrahim through his talk. Whereas at the time of Abdullah Badawi especially in the early phase of his reign, he had the full support of the people because of his promise to make a difference as to create a more democratic administration and meet the needs of the people. However, in the second phase of his reign civil disobedience reappear. The analysis shows that it stemmed from the factors of leadership, where Abdullah Badawi failed to deliver on the promise of change, family interventions in the administration, failed to solve the economic issues and also failed to address the issue of nonMuslims.

The analysis also showed that civil disobedience affected GE at the time of Dr. Mahathir and Abdullah Badawi. Civil disobedience resulted in the poor achievement by BN in GE 1999. The results of the 1999 election also shows BN still retained the two-thirds majority in parliament, but BN's performance deteriorated. The two states of Kelantan and 
Terengganu that have a majority of Malays had fallen into the hands of the opposition party (PAS). In general, the results of the 1999 General Election showed that BN only got 56.5 percent of the vote compared to 65 percent of the total votes in the 1995 general election. In terms of the number of parliamentary seats, BN won 148 seats out of 193 seats, compared to 166 seats it had won in the 1995 general election. See Table 1.

Table 1: Parliamentary and state seats won by BN and the Opposition in the 1999 general election

\begin{tabular}{|c|c|c|c|c|c|c|c|c|c|}
\hline \multirow[b]{2}{*}{ State } & \multirow[b]{2}{*}{$\mathrm{BN}$} & \multicolumn{3}{|c|}{ Parliamentary } & \multirow[b]{2}{*}{ PBS } & \multicolumn{2}{|c|}{ State } & \multirow[b]{2}{*}{$\mathrm{DAP}$} & \multirow[b]{2}{*}{$\mathrm{PKN}$} \\
\hline & & PAS & DAP & PKN & & $\mathrm{BN}$ & PAS & & \\
\hline Perlis & 3 & - & - & - & - & 12 & 3 & - & - \\
\hline Kedah & 7 & 8 & - & - & - & 24 & 12 & - & - \\
\hline Pulau Pinang & 6 & - & 4 & 1 & - & 30 & 1 & 1 & 1 \\
\hline Perak & 20 & 2 & 1 & - & - & 44 & 3 & 4 & 1 \\
\hline Selangor & 17 & - & - & - & - & 42 & 4 & 1 & 1 \\
\hline Kelantan & 1 & 10 & - & 3 & - & 2 & 41 & - & - \\
\hline Terengganu & - & 7 & - & 1 & - & 4 & 28 & - & - \\
\hline Pahang & 11 & - & - & - & - & 30 & 6 & 1 & 1 \\
\hline Negeri Sembilan & 7 & - & - & - & - & 32 & - & - & - \\
\hline Melaka & 4 & - & 1 & - & - & 21 & - & 4 & - \\
\hline Johor & 20 & - & - & - & - & 40 & - & - & - \\
\hline Sabah & 17 & - & - & - & - & - & - & - & - \\
\hline Sarawak & 28 & - & - & - & 3 & - & - & - & - \\
\hline Fedeeral Territory & 7 & - & 4 & - & - & - & - & - & - \\
\hline Total & 148 & 27 & 10 & 5 & 3 & 281 & 98 & 11 & 4 \\
\hline
\end{tabular}

Source: The Election Commission (2006a: 98-99)

Whereas at the time of Abdullah Badawi, civil disobedience caused BN to obtain the worst election results since GE 1974 in 2008 General Election. With a variety of issues that arose in the administration of Abdullah Badawi in the period 2006 to 2007, it was expected that BN would face a tough General Election. As a result, in the 2008 election BN failed to win two-thirds majority of parliamentary seats. BN also lost Kedah, Penang, Perak and Selangor and failed to recapture Kelantan. In the Federal Territory of Kuala Lumpur BN lost 10 of the 11 parliamentary seats. Such scenario led political analysts to say that Malaysia has been hit by a political tsunami. BN won 140 seats out of the total 222 parliamentary seats contested, while the opposition gained 82 seats which consists of the People's Justice Party (PKR) (31), DAP (28) and PAS (23) (Table 2).

Table 2: Parliamentary Seats Won by Political Party in the 2008 general Election

\begin{tabular}{lcccc}
\hline State & BN & DAP & PAS & PKR \\
\hline Perlis & 3 & - & - & - \\
Kedah & 4 & - & 6 & 5 \\
Pulau Pinang & 2 & 7 & - & 4 \\
Perak & 13 & 6 & 2 & 3 \\
Kelantan & 2 & - & 9 & 3 \\
Terengganu & 7 & - & 1 & - \\
Pahang & 12 & - & - & 2 \\
Selangor & 5 & 4 & 4 & 9 \\
Neg. Sembilan & 5 & 2 & - & 1 \\
Melaka & 5 & 1 & - & - \\
Johor & 25 & 1 & - & - \\
Sabah & 24 & 1 & - & - \\
Sarawak & 30 & 1 & - & - \\
Federal Territories & 3 & 5 & 1 & 4 \\
(K.L, Labuan dan Putrajaya) & 140 & 28 & 23 & 31 \\
Total & & & & \\
\hline
\end{tabular}

Source: The Election Commission (2008). 
In sum, civil disobedience happen in order to demand for the justice and a democratization process in Malaysia, but it is not able to bring the democratic process when BN is still in power and control the administrative practice and the same rules. Nevertheless, civil disobedience had a positive impact for causing a decline in BN achievement in 1999 and 2008 General Election.

\section{Conclusion}

This article has discussed the civil disobedience in the era of Dr. Mahathir and Abdullah Badawi. Civil disobedience had occurred since the reign of Tunku Abdul Rahman. However, the most serious civil disobedience was in 1998 with the advent of the Reform Movement in the final phase of the reign of Dr. Mahathir.Meanwhile, during the reign of Abdullah Badawi civil disobedience were eased and he was able to bring victory for the BN in 2004 general elction. However, in the second phase of Abdullah's government in 2007, civil disobedience appeared, which is one of the largest caused by HINDRAF and BERSIH. The factor causing the emergence of civil disobedience in 1998 was the sacking of Anwar Ibrahim by Dr. Mahathir, who was treated unfairly because people believe it had to do with a political conspiracy. While in the era of Abdullah Badawi's administration civil disobedience occured due to the weak leadership of Abdullah Badawi in some aspects like failing to keep his promises, family intervention in his administration, failing to solve the economic issues and mishandling of problems involving race and religion. Civil disobedience that occur during the reign of the two leaders had an impact on the results of 1999 election and 2008 general election. In the 1999 general election the BN especially UMNO lost the support of the people, especially the Malays. While in the 2008 election, a political tsunami occurred when BN failed to retain a two-thirds majority of the parliamentary seats and lost five states to the opposition. The results of the general election resulted in Abdullah Badawi's resignation and was replaced by Najib Razak in April 2009.

\section{References}

Bedau, H.A. (1991). Civil disobedience and personal responsibility for injustice. In. H.A. Bedau (ed.). Civil disobedience in focus (pp. 4967). London: Routledge.

Bersih. (2011). Introduction.[online] Available: http://bersih.org/?page_id=4111 (July 10, 2011).

Brown, G.K. (2004). Civil society and social movements in an ethnically divided society: the case of Malaysia, 1981-2001. Ph.D Thesis. University of Nottingham.

Bogdan, R. \& Biklen, S.K. (2007). Qualitative research for education: an introduction to theory and methods. Boston, Mass: Pearson Allyn \& Bacon.

Farish A. Noor. (1999). Looking for reformasi (reformation): the discursive dynamics of the reformasi movement and its prospects as a political project. Indonesia and The Malay World, 27(77), 8-15.

Francis LohKokWah. (2009). Old vs new politics in Malaysia. Petaling Jaya: SIRD.

Funston, J. (2000). Malaysia's tenth elections: status quo, reformasi or Islamization? Contemporary Southeast Asia, 22(1), 23-59.

Gatsiounis, I. (2008). Beyond the veneer: Malaysia's struggle for the dignity and direction. Singapore: Monsoon.

Hilley, J. (2001). Malaysia: Mahathirisme, hegemony and the new opposition. New York: Zed Books.

James Chin \& Wong Chin Huat. (2009). Malaysia's electoral upheaval. Journal of Democracy, 20(3), 71-85.

Johan Saravanamuttu. (2003). The eve of the 1999 general election: from the NEP to reformasi (reformation). In, Francis LohKokWah \& Johan Saravanamuttu (eds.), New politics in Malaysia, (pp.1-24). Singapore: Institute of Southeast Asian Studies.

Johan Saravanamuttu. 2008. A tectonic shift in Malaysian politics. In. Ooi Kee Beng, Johan Saravanamuttu\& Lee Hock Guan (eds.) March 8: eclipsing May 13, (pp. 33-79). Singapore: Institute of Southeast Asian Studies.

Lee Hock Guan. (2008). Malaysia in 2007: Abdullah administration under siege. Southeast Asian Affairs 2008, 187-206.

Lee, J.C.H. (2010). Islamization and activism in Malaysia: Petaling Jaya: Strategic Information and Research Development Centre.

Mahathir Mohamad. (2011). A doctor in the house: the memoirs of Tun Dr. Mahathir Mohamad. Petaling Jaya: MPH Group Publishing.

Maznah Mohamad. 2008. Malaysia-democracy and the end of ethnic politics? Australian Journal of International Affairs, 62(4), 441-459.

Means, G.P. (1991). Malaysian politics: the second generation. Singapore: Oxford University Press.

Merriam, S.B. (2009). Qualitative research: a guide to design and implementation. San Francisco: Josey-Bass Publishers.

Ooi Kee Beng. (2008a). Lost in transition: Malaysia under Abdullah. Petaling Jaya: Strategic Information and Research Development Centre.

Ooi Kee Beng. (2008b). The opposition's year of living demonstratively. In. Ooi Kee Beng, Johan Saravanamuttu \& Lee Hock Guan (eds.) March 8: eclipsing May 13, (pp.6-32). Singapore: Institute of Southeast Asian Studies.

Ooi Kee Beng. (2009). Arrested reform: the undoing of Abdullah Badawi. Kuala Lumpur: REFSA.

Rawls, J. (1971). A theory of justice. Massachusetts: Belknap Press.

Sheila Nair. (2007). The limits of protest and prospects for political reform in Malaysia. Critical Asian Studies, 39(3), 339-368.

Smith, W. (2004). Democracy, deliberation and disobedience. Res Publica, 10, 353-377. 
Election Commission. (1997). Reports of 1995 Malaysia General Election. Kuala Lumpur: PercetakanNasional Malaysia. Election Commission. (2006a). Reports of 1999 Malaysia General Election. Kuala Lumpur: PercetakanNasional Malaysia. Election Commission. (2006b). Reports of 2004 Malaysia General Election Kuala Lumpur: PercetakanNasional Malaysia. Election Commission (2008). Reports of $12^{\text {th }}$ Malaysia General Election. Kuala Lumpur: PercetakanNasional Malaysia.

Weiss, M.L. (1999). What will become reformasi? Ethnicity and changing political norms in Malaysia.Contemporary Southeast Asia, 21(3), 424-427.

Weiss, M.L. (2000). The 1999 Malaysian general elections: issues, insult, and irregularities. Asian Survey, 40(3), 413-435.

Weiss, M.L. (2003). Overcoming race-based politics in Malaysia: establishing norms for deeper multiethnic co-operation. In. Ho Khai Leong \& James Chin (eds.). Mahathir administration: performance and crisis in governance, (pp.62-99). Singapore: Times Books International.

Weiss, M.L. (2006). Protest and possibilities: civil society and coalitions for political change in Malaysia. Stanford: Stanford University Press. 